\title{
STRATEGIC LITIGATION AS A FRAMEWORK FOR THE PROTECTION OF INDIGENOUS RIGHTS. AN ANALYSIS OF SOME OF THE ACHIEVEMENTS, DIFFICULTIES AND CHALLENGES INVOLVED ${ }^{1}$
}

\author{
ASIER MARTINEZ DE BRINGAS*
}

\begin{abstract}
This study is structured into two clearly defined sections. Firstly, strategic litigation will be used as a framework to account for the developments and improvements made to indigenous rights as a result of the remarkable international effort to protect indigenous peoples. Some focal points in the production of strategic litigation discourse on indigenous rights and its guarantees will be considered. These will include the discourse produced by the United Nations and its related institutions in recent years specifically to solve the dramatic situation of indigenous peoples; and the discourse by the Inter-American Court of Human Rights (under the regional aegis of the OAS). Secondly, these developments will be contrasted with a crude diagnosis of reality by identifying the main difficulties and the real limits for the consolidation and implementation of indigenous rights. This will be followed by an outline of the challenges to be faced by indigenous peoples in the coming years, which will compel them to try new ways of political, normative, and strategic thinking.
\end{abstract}

Keywords: Strategic Litigation; Indigenous Peoples Rights; collective rights; autonomy; territoriality; criminalization.

Summary: 1. Introduction. 2. Progress, Progression AND ACHIEVEMENTS OF Indigenous Rights. 3. Conflicts and difficulties in guaranteeing indigenous Peoples' Rights. The Rugged path of indigenous CHALlenges. 4. ConClusions.

\section{INTRODUCTION}

Any discussion about indigenous peoples requires relying on an ideological analytical framework for both colonial and post-colonial issues. At the same time, talking about the rights of indigenous peoples entails exploring decolonising dynamics as a condition of possibility for these rights to exist; colonial history must be accounted for in order to understand how indigenous peoples were used and abused. Understanding the past of indigenous peoples is a condition of possibility for constructing a pedagogy of decolonisation and the dynamics involved. This is the endeavour of an indigenous grammar of rights: to construct an alternative History that involves alternative knowledge and other ways of understanding struggles and rights. Decolonisation crucially demands reconstructing indigenous peoples' epistemologies, discourses, worldviews and ways of

\footnotetext{
${ }^{1}$ The research leading to this publication has received funding through the project "Derechos humanos $\mathrm{y}$ retos socio-culturales en un mundo en transformación" (IT1224-19) of the Basque Government.

*Assistant Professor of Constitutional Law, University of Deusto, Spain (asier.martinezb@deusto.es)
} 
life, that have been ruined and trampled on. All this is required to give way to the next proactive and enunciative phase, in which the materiality of rights can be constructed based on the practices in the struggle for life, territory and indigenous autonomy as a collective expression of indigenous difference.

An analysis of globalisation in connection with indigenous peoples reveals a bleak picture that shows evidence of, and brings back, the shadow cast by colonialism. There are more than 370 million indigenous peoples living on the planet. Although they make up approximately $5 \%$ of the world's population, they represent dramatically high levels of poverty: they account for $15 \%$ of the world's poverty and $33 \%$ of the world's extreme poverty. However, indigenous peoples occupy a quarter of the earth's surface and protect and sustain $80 \%$ of the global biodiversity. Indigenous wisdom and life practices have operated as barriers to the predation of natural resources (IWGIA, 2019; 2020).

These data reflect the discriminatory and exclusionary impact of the colonial process on these peoples. Despite being the guardians of the Earth's resources due to their life practices and their spirituality, colonial globalisation hounds and discriminates against them in multiple ways. They are deprived not only of their territories and of the goods contained in them, despite being the rightful and original owners; but also of being citizens' of States that must meet their basic needs, which explains the indicators of extreme poverty identified with them. As guardians of biodiversity and key actors in the implementation of sustainable development and territorial management ${ }^{2}$ (through ancestral approaches of appropriation, production and territorial sustainability), they become the main targets for persecution. They are also criminalised by the powers of the State and other stakeholders in the exploitation of biodiversity as part of a discourse of progress and development. Therefore, original colonial deprivation of land and resources coexists with new and updated forms of postcolonial deprivation, whereby indigenous peoples shift from being the guardians of global sustainability to the victims of their own territories. This study is structured into two clearly defined sections. Firstly, strategic litigation will be used as a framework to account for the developments and improvements made to indigenous rights as a result of the remarkable international effort to protect indigenous peoples. Some focal points in the production of strategic litigation discourse on indigenous rights and its guarantees will be considered. These will include the discourse produced by the United Nations and its related institutions in recent years specifically to solve the dramatic situation of indigenous peoples; and the discourse by the Inter-American Court of Human Rights (under the regional aegis of the OAS). The latter is a fundamental actor in the construction of a significant and prolific jurisprudence on indigenous peoples; as well as in the creative construction of new legal categories with a purely collective approach, an entire litigation strategy to solve indigenous demands. The articulation, analysis and deployment of this collective dimension of rights will be one of the main threads of interest in this study.

\footnotetext{
${ }^{2}$ Crucially, these practices are merged to create and understand the collective identity of indigenous peoples and their rights.
} 
Secondly, these developments will be contrasted with a crude diagnosis of reality by identifying the main difficulties and the real limits for the consolidation and implementation of indigenous rights. This will be followed by an outline of the challenges to be faced by indigenous peoples in the coming years, which will compel them to try new ways of political, normative, and strategic thinking. Two elements will therefore be considered that are crucial to the consolidation of indigenous struggles and rights: the consultation of indigenous peoples in relation to the decisions to be taken regarding indigenous territories (who, how and what is decided); and the autonomy of indigenous peoples in terms of summarising and synthesising their proposals, which is a necessary mediation for the institutionalisation of indigenous ways of life and forms of development.

\section{Progress, Progression AND ACHIEVEMENTS OF INDIGENOUS RightS}

Since the entry into force of the ILO Convention 169 in 1989, there has been an unprecedented development of the agenda for indigenous rights, both in the International System for the Protection of Rights (UN), and in the Inter-American Human Rights System (IAHRS). The emergence of a solid international discourse on indigenous rights has meant that indigenous peoples have taken a significant stance on these Systems, their discourse and their institutional apparatus. This has led them to refocus their litigating strategy to rehearse and devise avenues of political and regulatory struggle. In this way the indigenous movement has shifted from its past positions based on struggle and claims for rights as a political strategy against the State, to new strategies of regulatory litigation that embrace and endorse the international discourse of human rights as one of the central axes of the indigenous struggle.

This has had some advantages, such as the rapid growth and institutionalisation of the indigenous discourse on rights at state, regional and international level. It has also brought about significant losses, including the abandonment of the political and strategic dimension of indigenous struggles. This has entailed subordinating the political potential of indigenous resistance to the mere regulatory strategy imposed by rights discourse, and the need to use its language, means of fighting, procedural timing, and techniques. The discourse of rights and strategic litigation thus becomes the main tool in the struggle for social justice, subsuming and constricting other forms of struggle and resistance that transcend legal language.

Some of the advances and steps that have taken place regarding the rights of indigenous peoples in the aforementioned protection Systems will now be systematised and accounted for in order to demonstrate the quantitative and qualitative progress involved in rights discourse and strategic litigation. ${ }^{3} 1$. The ILO Convention 169 opened up vast areas of work for furthering and guaranteeing indigenous rights. This was done using three paradigms or strategic frameworks. One was the collective ownership of rights. The Convention placed emphasis and energy on talking about 'indigenous peoples'

\footnotetext{
${ }^{3}$ An exclusive and exclusionary consideration of the approach to rights as a litigation strategy is extremely limiting, since it depoliticises other strategies for indigenous struggle such as civil disobedience, the right to disobey the Law.
} 
and not about populations or other derogatory names that prevented them from being considered subjects of collective rights in relation to indigenous issues. Collective ownership as peoples was reduced by refocusing its potential towards the value given to the concept 'peoples' in international law; that is, the only collective subjects that have been recognised are States. However, it provided a new scenario for the representation and functionalisation of collective ownership in human rights discourse and in litigation dynamics.

The second paradigm considered indigenous peoples' rights over their territory to be at the core of indigenous rights, as it gives meaning, completeness and scope to the rest of indigenous rights. The rights over the territory were expressed as a different way of understanding the forms of production, reproduction and development of indigenous life. They transcended the civil law approach to land, contracts, borders, and demarcation or delimitation; instead, they became the material and symbolic epicentre that endows indigenous autonomy and jurisdiction with meaning (Berraondo, 2016; Berraondo, 2006; Pentassuglia, 2011, p. 165 y ss).

The third paradigm advocated indigenous consultation as a procedural law mechanism to legitimise interventions on indigenous peoples' rights over their territory. Consultation thus entered the constellation of indigenous rights; however, its poor definition and delimitation has caused it to be instrumentally used by States and corporate groups against indigenous peoples.

2. A series of procedures and strategies for the protection of indigenous rights have been created, developed and perfected within the framework of the international system for the protection of human rights. The UN Permanent Forum on Indigenous Issues (UNPFII), established in 2000, is an advisory body to the Economic and Social Council (UN) with the mandate to provide the Council with technical advice on indigenous issues assist in the promotion of indigenous rights within UN programmes and projects. This has been done with ambivalent expertise and skill. The Forum has refined its work by focusing its topics for debate and discussion on the more political and central dimensions of indigenous rights. ${ }^{4}$ The topic of the 17th session of the UNPFII, namely 'Indigenous peoples' collective rights to lands, territories and resources' may serve to illustrate this. 3 . The United Nations Special Rapporteur on the rights of indigenous peoples has taken a leading role in the defence of indigenous rights as part of a special procedure by the UN Human Rights Council. The Rapporteurs have gathered vast information on violations of indigenous rights and made numerous recommendations to prevent and remedy these

\footnotetext{
${ }^{4}$ The Forum has been concerned with a multitude of issues that are essential for rethinking the breaches of indigenous rights, their guarantees of receiving reparation, and litigation strategies. It has decisively addressed significant matters and spaces to identify cases of exclusion and discrimination, such as the multiple discrimination against indigenous women and girls; the thorny topic of indigenous cross-border issues; militarisation in indigenous territory; commercial law of indigenous peoples; indigenous disability; deforestation; indigenous participation in exclusion systems; traditional indigenous knowledge; the impact of extractive industries; decolonisation; the truth commissions in relation to the dramatic repression suffered especially by indigenous peoples; fishing rights; and the special impact of climate change on these peoples, among others.
} 
violations. They have received and investigated violations of rights from both individual complaints and collective communications, which has led them to make numerous visits to countries to cross-check, regulate and denounce the situation of the rights of indigenous peoples. They have also compiled thematic and country-based reports to assess vulnerable situations and plan litigation strategies. The thematic viewpoint adopted by the current Rapporteur on central themes is interesting for understanding the vulnerability of indigenous peoples, and to gauge the main conflicts they face. An example was the thematic study on 'Attacks against and criminalisation of indigenous peoples defending their rights', ${ }^{5}$ which drew attention to a line of work in which rights mechanisms and litigation strategies should focus in the future. The thematic report on indigenous peoples and self-government was also politically very significant, as it established a seamless line between the right to indigenous self-determination exercised through autonomy and self-government, indigenous peoples' rights over their territory and indigenous forms of development, all of which are fundamental to guarantee a solid agenda for indigenous rights. ${ }^{6}$

4. The Expert Mechanism on the Rights of Indigenous Peoples is a subsidiary body of the Human Rights Council created in 2007. It is composed of seven independent members whose mandate is to provide advice and expertise on the rights of indigenous peoples as set out in the United Nations Declaration on the Rights of Indigenous Peoples. Its mandate was reviewed in 2016, and it monitors and guarantees the implementation of indigenous rights by visiting the States ${ }^{7}$ and reinforcing cooperation with other organs of the United Nations Human Rights treaties. The thematic focus of this Mechanism are the main areas that are under threat in connection with the protection of the rights of indigenous peoples. As a result, a thematic study on Free, Prior and Informed Consent was conducted with a view to continuing and complementing the work of the Special Rapporteur on the rights of indigenous peoples on this matter, carried out in previous years by James Anaya. ${ }^{8}$

\footnotetext{
${ }^{5}$ The study addresses the hostile reality of human rights defenders, with special interest in indigenous rights defenders. It sets out a series of measures necessary for prevention of violations and protection of the rights of defenders. Additionally, it documents the increasingly drastic and worrisome criminalisation of indigenous peoples defending their rights and the threats that they are systematically subject to, especially when they exercise their territorial rights and defend the natural resources adjacent to them. The study also examines the underlying, deep factors that ultimately cause the criminalisation of groups and peoples that devise a rights protection strategy in connection with ecological and territorial issues. Cf. Report of the Special Rapporteur on the situation of human rights and fundamental freedoms of indigenous people, Victoria Tauli Corpuz, Doc. A / HRC / 39/17, 10 August 2018.

${ }^{6}$ Report of the Special Rapporteur on the situation of human rights and fundamental freedoms of indigenous people, Victoria Tauli Corpuz, Doc. A / 74/149, 17 July 2019 para. 23.

${ }^{7}$ She inaugurated this new dimension of her mandate (assistance and advice to States) by visiting the Philippines and Mexico City In 2018.

${ }^{8}$ Study of the Expert Mechanism on the Rights of Indigenous Peoples 'Free, prior and informed consent: a human rights-based approach', A / HRC / 39/62, 10 August 2018, paras. 6-8. Clearly relying on colonial aspects, the Expert Mechanism report argued that the right to self-determination is the fundamental human right on which free, prior and informed consent is grounded, strongly linked to the indigenous right to autonomy and self-government. It establishes that the articulation of prior, free and informed consent as a right has a three-fold purpose: i) to ensure that indigenous peoples recover control over their lands and
} 
5. One of the great advances in the area of indigenous rights was the approval of the United Nations Declaration on the Rights of Indigenous Peoples (the Declaration), which serves as a core project on the basis of which a comprehensive programme for indigenous rights protection and litigation can be implemented. It is the regulatory conclusion of the many years of indigenous struggle in the United Nations. The Declaration demonstrates a clear paradigm shift in the understanding and assertion of indigenous rights. Indigenous self-determination is the corner stone of the Declaration, as a fundamental right on which all individual and collective expressions of indigenous rights can be comprehended. This is supplemented by the need for indigenous self-identification, as criterion for affiliation to know who feels indigenous. This is the result of the heuristic role that selfdetermination plays in the Declaration; not only as a collective project and but also in its individual dimension, which involves internal self-determination to declare oneself indigenous, beyond any limiting and excluding external affiliations. The spirit and aim of the Declaration also relates to the determination to establish prior, free and informed consent as a preparatory right to develop indigenous peoples' litigation strategies for selfdetermination, rights over their territory and regulatory systems. It is not, therefore, one more right, nor is it an instrumental or functional right. The spirit of the Declaration is that Consent (not its degraded version in the form of an indigenous consultation) should operate as an interpretive seed for the implementation of other rights, such as indigenous peoples' autonomy and rights over their territory.

6. As part of the framework put in place to guarantee the protection of indigenous rights in International Human Rights Law, it is also necessary to note the role played by the Committee on the Elimination of Racial Discrimination (CERD), the Committee on Economic, Social and Cultural Rights (CESR), the Human Rights Committee (HRC), the Committee on the Rights of the Child $(C R C)$ and the Committee on the Elimination of Discrimination against Women (CEDAW), among others. These committees make a determined effort to interpret the rights and engage in strategic litigation work aimed at including other forms of discrimination and violation that strictly affect indigenous peoples. They also attempt to integrate the Declaration into the interpretative standards for all human rights.

7. The CERD has been creatively taking steps for the protection of rights relating to racial discrimination in its collective dimension. To do so, it has used procedures such as early warning and urgent actions and has considered how multiple, intersectional discrimination typically affects indigenous peoples, particularly vulnerable groups. The CERD has shown how a fundamental discrimination, namely colonial dispossession (of property, of rights, of identities, of territories, of culture, of knowledge), has been a stepping stone to other forms of discrimination relating to a classical conception of rights (education, life, language rights, housing, food, etc.).

resources; ii) to restore indigenous peoples' cultural integrity, pride and self-esteem; and iii) to redress the power imbalance between indigenous peoples and States (para. 11). This lay the foundations for understanding the seamless, circular nature of the restorative and redressing process relating to indigenous collective rights: indigenous autonomy is interdependent with rights over the territory and prior, free and informed consent. 
Under General Comment 23 on indigenous peoples, the CERD has made indigenous peoples a central, collective subject to be analysed and protected, as they are affected by multiple intersecting and cross-sectional forms of discrimination, both individual and collective. It defines the new types of indigenous discrimination, including the denial of self-identification (as opposed to exclusive external designation); the denial or limitation of indigenous peoples' self-determination, a necessary condition for the assertion of other rights; the selective and instrumental use of indigenous Consultation and consent; territorybased discrimination, through dispossession, violence or expulsion; indigenous structural discrimination in the context of socio and employment relations; and discrimination in terms of access to healthcare and treatment, of access to education, of housing and of the practice of justice. ${ }^{9}$ The Committee conducted a review of discrimination based on the colonial dispossession of indigenous peoples. It provided a view of classic individualised ways of understanding discrimination that was interdependent and interconnected with some forms of collective discrimination resulting from the specific way that the rights of indigenous peoples are understood and exercised. 8. General Observation 24 of the CESR, for its part, made an intercultural interpretation of the violations of certain rights to accommodate and protect indigenous peoples, considered to be one of the most vulnerable groups, as they have been dramatically affected by the harmful action of the 'business activities' that take place in their territory. ${ }^{10}$ The CESR has sought novel, strategic interpretations, facilitating an interdependent understanding of the individual and collective dimensions. It has taken distance from the classic interpretation of rights as isolated and atomised units. The CESR has advocated the "cultural values' ${ }^{11}$ of indigenous peoples, since any business endeavour that distorts and affects these values involves a breach in the chain of indigenous collective rights. The need for free, prior and informed consent is also emphasised in relation to 'all matters that could affect their rights', in order to assess the impact that these actions have on the entire chain of rights. The CESR firmly stated that companies should consult indigenous peoples through their representative institutions in order to obtain free, prior and informed consent. ${ }^{12}$ The term 'expressive violence' can be used when referring to individual violations that are strategically projected onto the collective dimension. They produce a systemic link between these two elements, so the violations of individual rights cause breaches in the overall group; and a broken community - (community/people) cannot guarantee the autonomy and freedom of the indigenous people it represents. Expressive violence takes shape and is materialised through the actions of businesses in indigenous territory, strongly affecting the daily lives of indigenous peoples and their productive capacity. In this way, they also impinge on many indigenous social rights: health, education, employment, living spaces, language, etc. The interdependence of rights causes collective violations that affect social rights at the same time as in their individual dimension.

\footnotetext{
${ }^{9}$ General Recommendation No. 23.

${ }^{10}$ Committee on Economic, Social and Cultural Rights, General Comment No. 24, E / C.12 / GC / 24, 10 August 2017, para. 8.

${ }^{11}$ It was specifically noted the adverse consequences that the violation of these values entails for the rights over the territory, resources, cultural heritage, traditional knowledge and culture of indigenous peoples, Ibid, para. 17.

${ }^{12}$ Ibid., para. 12, 17. Cf. In this regard, see Human rights and transnational corporations and other business enterprises, A / 68/279, para. 31; United Nations Declaration on the Rights of Indigenous Peoples. Guiding Principles for Business Enterprises, UN, 2013, p. 26; A / HRC / 33/42; and A / 66/288, paras. 92 to 108.
} 
The CESR also made an important reference to the right of indigenous peoples to control the intellectual property over their cultural heritage: their traditional knowledge and cultural expressions. ${ }^{13}$ In this way, the CESR decolonised the influence that may be exerted on indigenous peoples' cultural rights, limiting the actions of States and businesses. 9. The Human Rights Committee's General Comment 36 (2018) identified deprivation of land, territories and resources of indigenous peoples and environmental degradation as important effects on indigenous peoples' right to life. It therefore established an interdependent connection between individual and collective rights, based on the right to life. ${ }^{14}$

10. The Committee on the Rights of the Child has made a critical diagnosis of the cumulative discrimination experienced by indigenous children discrimination. It highlighted the particularly vulnerable nature of this group and the exclusionary discrimination to which this group is subjected, especially in access to medical care, and basic and intercultural education. This has become chronic in Guatemala, El Salvador, Panama and Argentina. The extreme vulnerability of this group due to poverty and malnutrition and the working conditions and social exploitation of indigenous children in Guatemala are particularly remarkable. ${ }^{15}$ This report stresses the impact that extractive mining and the industrial exploitation of farming has on the living conditions and future of indigenous children; and the damage that forced evictions causes on indigenous children in the affected communities. ${ }^{16}$

11. The Committee on the Elimination of Discrimination against Women also highlighted the intersectional discrimination faced by indigenous women and girl ${ }^{17}$. It emphasised the lack of representation of women in community decision making, and the discrimination they experience in access to justice and to land ownership. In General Comment 27 (2018), it established a structural connection between the effects of climate change and its special impact on indigenous women. ${ }^{18}$ One of its new contributions was noting the direct and harmful impact that climate change produces on the most vulnerable groups and communities, especially indigenous peoples, because of their special relationship with the land and its resources. It emphasised the special impact that climate changes produce on indigenous women, as main subjects involved in the production, reproduction and development of territories/bodies, and of the resources linked to them. As a result, indigenous women were granted special protected status - based on the indigenous territory/body. They are a leading group in the sustainability of the territory and are therefore especially vulnerable to the emergence of a new paradigm of conflicts: ecological and territorial conflicts. ${ }^{19}$

\footnotetext{
${ }^{13}$ Ibid., para. 24.

${ }^{14} \mathrm{HRC} / \mathrm{C} / \mathrm{GC} / 36$.

${ }^{15} \mathrm{CRC} / \mathrm{C} / \mathrm{GTM} / \mathrm{CO} / 5-6$; $\mathrm{CRC} / \mathrm{C} / \mathrm{PAN} / \mathrm{CO}$ / 5-6; $\mathrm{CRC} / \mathrm{C} / \mathrm{ARG} / \mathrm{CO}$ / 5-6; $\mathrm{CRC} / \mathrm{C}$ / $\mathrm{SLV}$ / CO / 5-6; $\mathrm{CRC} / \mathrm{C} / \mathrm{NOR} / \mathrm{CO} / 5-6$.

${ }^{16} \mathrm{~A} / \mathrm{HRC} / 39 / 17 / \mathrm{Add} .3$, para. 95-96.

${ }^{17} \mathrm{CEDAW} / \mathrm{C} / \mathrm{SUR} / \mathrm{CO}$ / 4-6; CEDAW / C / CHL / CO / 7; CEDAW / C / FJI / CO / 5; CEDAW / C /SUR / $\mathrm{CO} / 4-6$; CEDAW / C / MEX / CO / 9; CEDAW / C / NPL / CO / 6; CEDAW

${ }^{18} \mathrm{CEDAW} / \mathrm{C} / \mathrm{GC} / 37$.

${ }^{19}$ In 2018, indigenous peoples achieved two important milestones under the United Nations Framework Convention on Climate Change. The Facilitating Working Group was created for the optimal functioning of
} 
12. Finally, within the Inter-American Human Rights System (IAHRS), the highest jurisdictional body for the protection of human rights in the regional framework of the OAS is the Inter-American Court of Human Rights (IACHR). Another fundamental human rights body within the IACHR, the Inter-American Commission, has prepared a series of innovative thematic reports on the situation of indigenous women, the impact of extractivism as an emerging conflict for indigenous peoples, and an analysis of the situation and problems of isolated indigenous peoples. These reports have detailed emerging human rights violations, emphasising specific nature of indigenous peoples as subjects of law, and the need to design special forms and mechanisms of protection, as well as new possibilities for strategic litigation.

What follows is a review of some judgments from the Inter-American Court of Human Rights (IACHR) that have highlighted the collective identity of indigenous peoples' rights, and their different nature from other issues and other subjects. The IACHR has established its own grammar and discourse in the interpretation of indigenous rights of great heuristic value, thus separating itself from the basic unit of rights analysis: that of the liberal individual subject. In the selection discussed here, the focus is on those judgements that show the indigenous specific nature, both in terms of culture and of worldview, which account for the collective quality of these peoples. These judgements emphasise indigenous self-identification as a fundamental criterion for affiliation, avoiding regulations of who is indigenous and how to be indigenous imposed from outside the worldview of indigenous peoples, either individually or collectively. These judgments account for indigenous collective materiality and community morphology through indigenous peoples' own specifically developed regulatory criteria: subjectivity, legal personality, personal integrity within a collective project, collective life, right of ownership of land and natural resources, indigenous peoples' own organisational modes, collective violation, etc. This is intended to devise indicators, guarantees and protection mechanisms for collective rights that may consider material and immaterial reparation in purely collective terms, beyond the individual unit of analysis of rights discourse (Nash Rojas, 2008, pp. 61-86; Estupiñan Silva e Ibañez Rivas, 2014, pp. 301-336). All this material anticipates a fresh, creative litigation strategy in legal operators such as the IACHR.

(i) The first judgments that will be discussed are those that emphasise the specificity of indigenous and tribal peoples as subjects of law, with their own collective subjectivity, different from other identities, minorities and peoples. The IACHR has made a broad interpretation of the concept of indigenous peoples to ensure that the protection of these rights is guaranteed; not only for the original indigenous peoples (the first and main victims of colonial dispossession) but also for those community identities that are synchronous and parallel effects of colonialism (Dulitzky, 2010, pp. 13-48). This was the case of the Saramaka community, based in Suriname, which was subject to colonial discipline. This involved the displacement of black communities from Africa to Latin America. The IACHR concluded that these communities had been placed in a situation where they lacked protection and therefore were vulnerable in a similar way as indigenous

the Platform of Local Communities and Indigenous Peoples. The Green Climate Fund was established and it adopted a specific policy for indigenous peoples. All of these were pioneering achievements for indigenous peoples in the fight for their rights, and in recognition of their special role in fighting climate change. 
peoples were (Brunner, 2008, p. 699). For the IACHR, tribal peoples share distinctive social, cultural and economic characteristics, including their special link to their ancestral territories, which require adopting special protection measures, similar to those developed for indigenous peoples by the International Human Rights System. ${ }^{20}$

(ii) Indigenous self-identification is related to the above, as it involves affiliation to a group. The Declaration took a new approach to provide better protection of the indigenous subject of rights, avoiding any external regulatory identification with criteria outside the indigenous way of understanding cultural identity and affiliation.

The IACHR established that determining whether a member of a community may lose certain indigenous (affiliation) rights if $\mathrm{s} / \mathrm{he}$ lived outside the specific territory of the community must only be the community's decision, based on internal criteria, and not the State's. In addition, the lack of individual identification with certain community and collective traditions by certain members cannot be seen as a reason to deny a community its collective rights. ${ }^{21}$ Community identification is a 'historical and social fact', which is part of the right to autonomy; hence the State must respect the form of self-identification of a community, ${ }^{22}$ as this is one of the core powers of communal ownership.

In another case, the IACHR ruled that contradictions in self-identification or ethnicity cannot be used as grounds to deny communal ownership of their traditional land. ${ }^{23}$ Lack of awareness of the status of a community as an 'original people' does not imply the loss of collective rights that may be incumbent on them, nor the subsequent appropriate State obligations, despite the lack of awareness of this collective status. ${ }^{24}$ Selfidentification is preferred as a criterion to determine who is part of a community or people to any form of State identification .

(iii) Another fundamental issue where the IACHR has clarified the applicable criteria has been the collective consideration of victims of human rights violations. Do violations of indigenous rights affect a community as if it were a whole, thus establishing the community as the basic unit of measurement of the communal? Is there room for considering these violations as collective damage? Or should the individual victims (one by one) be considered in any assessment of damages, taking the individual as the unit of measurement instead of the community?

In the Saramaka case, the IACHR did not speak of the Saramaka people as having communal ownership. Rather, it relied on the individual's right to ownership and the damages caused. The guarantees and reparations were established as if there had been

\footnotetext{
${ }^{20}$ I/A Court H.R. Case of the Saramaka People v. Suriname. Preliminary Objections, Merits, Reparations, and Costs (POMRC). 2007, paras. 84 and 86.

${ }^{21}$ Ibid., para. 164

${ }^{22}$ Ibid., paras. 43 and 49.

${ }^{23}$ I/A Court H.R. Case of the Xákmok Kásek Indigenous Community v. Paraguay. Merits, Reparations, and Costs (MRC). 2010, para. 33.

${ }^{24}$ I/A Court H.R. Case of the Garifuna Triunfo de la Cruz Community and its members v. Honduras. Merits, Reparations, and Costs (MRC) 2015, para. 57.
} 
individual violations of rights. A change occurred in the Xákmok Kásek ${ }^{25}$ case, in which Judge Vio Grossi advised that true reparation called for a considering indigenous peoples as such as victims, which required recognising the collective nature of the right and, therefore, of any appropriate reparations. This jurisprudential argument became settled in the Sarayacu case, when considering the violation of the right to communal property, which required a new way of thinking about reparations in collective terms, both in their material and immaterial dimensions. ${ }^{26}$

(iv) The recognition of the legal personality of the community is a procedural guarantee that allows the communal rights that have been recognised for indigenous peoples to be implemented and operationalised. Social status enables indigenous peoples to enjoy certain communal rights, beyond them being merely rhetorically or discursively recognised. Legal personality is a condition of possibility for the enjoyment of indigenous rights over their territory and its material contents, in other words, for this right to be procedurally asserted. This recognition is an added guarantee and a parameter that can be used to know if someone is the owner of a communal right and can exercise it as such. ${ }^{27}$

(v) Regarding the right to life, in the case of the Plan de Sánchez massacre (Guatemala), both the Commission and the victims asked the IACHR to define the massacre as genocide. It was considered that the ultimate aim of this massacre was to end the organic and institutional life of an entire community as a people. The mobilising animus was to destroy communal identity as a life structure settled in a territory. The IACHR established that it had no competence beyond the Inter-American System of Rights, while clarifying that these events had seriously affected the Mayan people's communal structure of identity and values, which undoubtedly transcended an atomised understanding and the consideration of individual damages. This aggravated the impact, as it was qualified as communal, which should be taken into account in the reparations. ${ }^{28}$

In another case, the execution of the community leader Escue Zapata by the Colombian army was claimed by representatives of the victims as being an act that went beyond a mere individual execution. Escué was murdered because of his status as a leader, as a representative of the traditional authority of his people. He was an institutional signifier of the community, which transcended the mere individual violation of a right. It was clearly aimed to harm the collective fabric of a community; to fracture and intimidate the communal structures of a people. ${ }^{29}$

\footnotetext{
${ }^{25}$ I/A Court H.R. Case of the Xákmok Kásek Indigenous Community v. Paraguay. Merits, Reparations, and Costs (MRC)2010. Concurring opinion of Judge Eduardo Vio Grossi, paras. 25 and 26.

${ }^{26}$ I/A Court H.R. Case of the Kichwa Indigenous People of Sarayaku v. Ecuador. Merits and reparations (MR). 2012, para. 231.

${ }^{27}$ I/A Court H.R. Case of the Sawhoyamaxa Indigenous Community v. Paraguay. Merits, Reparations, and Costs (MRC)2006, para. 189-190.

${ }^{28}$ I/A Court H.R. Case of the Plan de Sánchez Massacre v. Guatemala. Merits. 2004, paras. 42.7; 42.12; 42.21 .

${ }^{29}$ I/A Court H.R. Case of Escué Zapata vs. Colombia. Merits, Reparations, and Costs (MRC) 2007, para. 54.
} 
The same would happen in other cases, such as Xákmok Kásek vs. Paraguay; Yakye Axa vs. Paraguay; Sawhoyamaxa vs. Paraguay, in which the IACHR considered that the State had not taken appropriate measures to respect and protect the right to a decent life of all persons in the community, which implied a densely communal interpretation of the right to life and its related issues, something that went far beyond the classic individual interpretations of this right. ${ }^{30}$

(vi) The IACHR has also considered violations of personal safety to have clearly communal scope and effects. Making the remains of a loved one killed by state agents disappear, depriving the community of their right to grieve and causing communal suffering due to the spiritual significance of the disappearance of a body goes far beyond the individual damage. ${ }^{31}$ In other cases it has been deemed that the intent to produce systematic damages to the communal structure implies additional, qualified suffering, which leads to collective emotional, spiritual and psychological imbalances that go beyond a mere individual appraisal. ${ }^{32}$ In the Río Negro massacre, after the extrajudicial killings of indigenous victims were perpetrated, their bodies were burnt and buried in open graves. This was intended to go beyond the mere individual damage caused by murders or summary killings; it was aimed at harming the entire spiritual and religious dimension of these peoples, preventing their transpersonal transit to other realms of life through indigenous ritual and ceremony, a fundamental form of reparation in communal cosmogonies. The IACHR not only recognised this as being a clear violation of the collective right to personal safety, but a violation of the right to freedom of conscience and religion. ${ }^{33}$ The special link between these civil rights and indigenous spirituality and worldview grant them a communal, more profound dimension, related to how conscience and religious freedom are interpreted in liberal terms.

(vii) Regarding indigenous people's difficulties in gaining access to justice, the IACHR established that the victim's cultural identity demanded making an interpreter available to avoid rendering her vulnerable, as indigenous peoples usually are in their involvement with State justice. ${ }^{34}$ Beyond the scope of the IACHR, it would be necessary to connect this issue with the right to legal pluralism from an intercultural perspective. The right to have an interpreter transcends an individualised consideration of access to justice, which is defined by the right to be understood and understand the procedural logic of the State. This right must operate as an intercultural bridge for indigenous peoples to access and understand justice, beyond its mere formal dimension. The role of the interpreter is to act as an intercultural hermeneutic actor for translating indigenous normative systems into State logic and to inform about the rights and guarantees that the State offers to the indigenous party.

\footnotetext{
${ }^{30}$ I/A Court H.R. Case of the Yakye Axa Indigenous Community v. Paraguay. Merits, Reparations, and Costs (MRC) 2005, para. 162-165; I/A Court H.R. Case of the Sawhoyamaxa Indigenous Community v. Paraguay. Merits, Reparations, and Costs (MRC)2006, para. 155-156; I/A Court H.R. Case of the Xákmok Kásek Indigenous Community v. Paraguay. Merits, Reparations, and Costs (MRC)2010, paras. 223-234.

${ }^{31}$ I/A Court H.R. Case of Bámaca Velásquez vs. Guatemala. Reparations and Costs (RC). 2002, para. 81

${ }^{32}$ I/A Court H.R. Case of the Xákmok Kásek Indigenous Community v. Paraguay. Merits, Reparations, and Costs (MRC)2010, para. 244.

${ }^{33}$ I/A Court H.R. Case of the Massacres of Río Negro v. Guatemala. Preliminary Objections, Merits, Reparations, and Costs (POMRC) 2012, paras. 154-165.

${ }^{34}$ I/A Court H.R. Case of Tiu Tojín vs. Guatemala. Merits, Reparations, and Costs (MRC) 2008, para. 97.
} 
(viii) One of the IACHR's greatest efforts and advances in the field of communal rights has been aimed at bringing intercultural regulatory foundations to the right to indigenous peoples' communal property. This is goes beyond the narrow scope of private property under the American Convention, both materially and formally. In principle, the IACHR does not recognise, the right to indigenous communal property as such. For this reason, the IACHR has developed an intercultural interpretation of Article 21 of the American Convention on Human Rights (ACHR), which not only fits the liberal concept of private property, but also a material interpretation of the indigenous communal right. The IACHR has also recognised the pre-state character of indigenous peoples' communal property right and accepted conventional protection for these two dimensions and interpretations of property (private and communal). indigenous peoples' communal right is therefore a substantive, original right, with a temporary and logical priority that sits above State private property; but it is also a right to reparation, intended to correct the uses and abuses of colonialism. That is the interpretative line that the Court would use in other territory-based conflicts (Citroni y Quintana, k, 2008, pp. 317 y ss.).

The IACHR considers that Article 21 of the ACHR, ILO Convention 169, the Declaration, together with the internal legislation of the individual States and international human rights law, constitute a 'corpus iuris' that provide new criteria relating to the duties of States in terms of indigenous territory-related rights. ${ }^{35}$

The substantive dimension of indigenous peoples' communal rights is articulated by the IACHR based on the special relationship that indigenous peoples have with their territory. It is fundamental for maintaining their culture, spiritual life and economic survival and preserving the safety of their territory and its transmission to future generations ${ }^{36}$ It emphasises, therefore, the importance of this relationship to the territory the production, reproduction and development of these peoples' lives, from the point of view of culture, economy and worldview. Any discussion of indigenous territories also includes natural resources and subsoil resources, a natural expression of a holistic conception of the territory, and the rights that go beyond private property. The denial of indigenous peoples' rights over their territory would therefore be a violation of these peoples' right to communal life. Therefore, ownership of the territory on indigenous terms (appropriation, use, possession, historical occupation and intergenerational transmission) serves as a legitimate practice for official recognition by the State, regardless of the existence of ownership titles that characterise the logic of civil law. ${ }^{37}$ There is an important consequence of this: the exercise of this right is not conditional upon its recognition by the State; communal property is prior to the State's legal titles (as established by the IACHR in the Awas Tigni case ). This precedes a hypothetical social contract with the State, and thus, the proprietary logic that demands titles to secure and justify land ownership.

\footnotetext{
${ }^{35}$ I/A Court H.R. Case of the Garifuna Triunfo de la Cruz Community and its members v. Honduras. Merits, Reparations, and Costs (MRC) 2015, para. 103.

${ }^{36}$ I / A Court HR. Case of the Mayagna (Sumo) Awas Tingni Community v. Nicaragua. Merits, Reparations, and Costs (MRC) 2001, para. 149; I / A Court HR. Case of the Yakye Axa Indigenous Community v. Paraguay. Merits, Reparations, and Costs (MRC)2005, para. 131.

${ }^{37}$ I / A Court HR. Case of the Sawhoyamaxa Indigenous Community v. Paraguay. Merits, Reparations, and Costs (MRC)2006, para. 128.
} 
As a result of the protection given by Article 21 of the ACHR both to indigenous peoples' right to communal property and to private property, the IACHR has made a dialectical interpretation of these conflicting rights. Thus, if a community loses possession of its territory - as a result of colonial dispossessions beyond its control - it will always maintain the right of ownership over them, without the need for legal title, unless these have been legitimately transferred to third parties that acted in good faith. Faced with this controversial conflict, in which the restitution of indigenous rights directly collides with the right to private property by third parties that acted in good faith, the IACHR has made an integrative hermeneutic analysis and demanded a proportionality test (which includes appropriateness, necessity, and strict weighing. ${ }^{38}$ This is the ultimate criterion to discern what exactly are the preponderant legal assets in the cases where conflicting rights collide: either third parties' private property or communal property. Given the colonial drift of indigenous territory dispossessions in Latin America, the interpretation based on considering which the most vulnerable group is (indigenous peoples) may be seriously affected. This in turn may have an impact on other fundamental rights intertwined with indigenous peoples' right to their territory (life, cultural integrity, economic survival, health, education, etc.). Therefore, an intercultural and holistic interpretation of indigenous vulnerability is called for that accounts for potential communal fractures.

\section{CONFLICTS AND DIFFICULTIES IN GUARANTEEING INDIGENOUS PEOPLES' RIGHTS. THE RUGGED PATH OF INDIGENOUS CHALLENGES}

This section discusses the main difficulties and the actual fabric of the conflicts that indigenous peoples are currently encountering in order to guarantee their rights. The aim is to shed some light on some of the challenges that indigenous peoples face at present and will face in the coming years, as well as the focus to be adopted by the strategic litigation regarding indigenous peoples' rights in the future.

1. An initial outline of the difficulties involved is related to the gap between (i) the rapid and intense process of creating a grammar of indigenous rights, together with the development of an imposing institutional architecture for its articulation at state, regional and international levels; and (ii) the difficulty in ensuring the actual protection of indigenous peoples' rights, as evidenced by their systematic violations. This is what has been called an increase in the 'implementation gap', ${ }^{39}$ the immeasurable split between the positivisation of indigenous rights and their real effectiveness (Aylwin, 2014, pp. 282294; FILAC, 2019). This mismatch and asymmetry between the discourse of rights and the actual situation brings an additional major problem to the fore: the crisis of the

\footnotetext{
${ }^{38}$ Case of the Yakye Axa Indigenous Community v. Paraguay. Merits, Reparations, and Costs (MRC)2005, para. 144.

${ }^{39}$ Both Stavenhaguen and the Permanent Forum have drawn attention to this issue. Nietzsche stated that liberal institutions cease to be liberal as soon as they are attained. In this sense, when a communal form of 'we indigenous people' manages to obtain the rights that it demands and enable the use of specific litigation strategies, the 'we' condition is diluted and the individual logic emerges, depoliticising collective subjectivities. This is the destructive effect of the implementation gap. Cf. Report of the Special Rapporteur on the situation of Human Rights and fundamental freedoms of indigenous people, UN doc. E / CN.4 / 2006/78 / Add.2, December 152005.
} 
rights strategy (of strategic litigation in general) as the main way of confronting the real damages and exclusions caused to indigenous peoples. This mismatch produces a strong depoliticisation of viable practices and tactics, a great erosion of the effectiveness and legitimacy of rights. This introduces a new logistic paradigm on how to understand and face rights as a practice of transformation and emancipation. The question is: What is the emancipatory force of only using the indigenous peoples' rights approach (as a normative strategy) if other approaches such as resistance or civil disobedience are rendered void and depoliticised as a complement to the indigenous rights strategy?

2. A second group of difficulties follows from the exacerbated and exponential increase in indigenous territorial conflicts around the world. ${ }^{40}$ Although there have been some positive and significant advances in the construction of a regulatory language aimed at the recognition and protection of indigenous communal property, and of indigenous peoples' rights over their territory as the basis of individual and collective life; the systematic, repeated attacks on indigenous peoples have shown that the rights discourse and the strategic litigation through which it operates continue to be weak, and the 'implementation gap' seems to be here to stay (Salmon, 2010, pp. 80 y ss.).

3. There is also a progressive instrumentalisation and inversion of the content of other indigenous rights that are key to the indigenous peoples' political agenda. Two paradigmatic examples are the treatment of the Consultation and of indigenous peoples' autonomy.

3.1. Free, prior and informed Consultation has become a central issue for the exercise and application of indigenous peoples' rights. Articles 6, 7, 15 and 16 of ILO Convention 169 establish that governments must consult the indigenous and tribal peoples concerned whenever consideration is given to legislative or administrative measures which may affect them (Articles 6 and 7), or to any programmes for the exploration or exploitation of resources pertaining to their lands (Article 15). The Convention also specifically mentions that the indigenous communities concerned shall be taken into account in the formulation, implementation and evaluation of plans and programmes for national and regional development which may affect them directly (Articles 6 and 7), and that, when the relocation of these peoples is considered necessary as an exceptional measure, such relocation shall take place only with their free and informed consent (Article 16.2). Similarly, the United Nations Declaration on the Rights of Indigenous Peoples specifically states that indigenous peoples should be consulted before adopting legislative and administrative measures that affect them; and before approving any project that may have an impact on their lands or territories, and the resources surrounding them. In a similar vein, it establishes that free, prior and informed consent is essential in cases of transfers or relocations of communities (Articles 10, 19, 30 and 32). Additionally, it contains some provisions on situations not covered by Convention 169, more precisely, by specifying the type of measures that indigenous peoples' should be consulted on. For example, it provides the duty to consult the indigenous peoples concerned before

${ }^{40}$ El Mundo Indigena 2019 is an excellent report on the root causes of indigenous territory-based conflicts, and the impact that these conflicts have on indigenous peoples' life chain. 
using their land or territory for military activities (Article 30), which was not specifically contemplated in Convention 169. ${ }^{41}$

The IACHR has recognised that Consultation is a 'general principle of International Law' based on the close relationship that indigenous peoples have with their territory; on the importance that communal property has for them; and on their cultural and spiritual ties they have with it. ${ }^{42}$ In addition, for the IACHR, Consultation is closely linked to the right to political participation contained in Article 23 of the ACHR, in connection with any decisions that may affect indigenous rights and interests that are made without their participation. Consultation is, therefore, an integral part of indigenous peoples' right to self-determination.

Rapporteur James Anaya maintained that, although the Declaration and ILO Convention 169 stated that consultations with indigenous peoples should be held in good faith, in order to obtain their free, prior and informed consent, these international instruments cannot be considered to give indigenous people a general right of veto. ${ }^{43}$ For the Rapporteur, consent should ideally be the ultimate result of any consultation process carried out in good faith, whether on large-scale investment projects, on medium or small-scale projects, or on any other issues that may affect the interests of indigenous peoples. The duty to consult is a remedial right that has arisen to put an end to historical colonial models that have been imposed on indigenous peoples and threatened their living conditions. However, it can never be a veto 'to unilaterally impose their will on States when the latter act legitimately and faithfully in the public interest. ${ }^{44}$

Following this thorny distinction between Consultation and consent, which concluded with the more than controversial final corollary of Rapporteur Anaya on the fact that the consultation does not grant a right of veto to indigenous peoples, the dynamics of Consultation in Latin America entered a process of instrumentalisation and 'administrativisation'; as a result, the exercise of this right is left to States and businesses, rather than to indigenous peoples. Administrativisation is a technique to render the right void in terms of consultation, and to make other subjects (States and/or businesses) the key players. What was a duty of States, companies and third parties who were present in indigenous peoples' territory has turned into their right.

The process of administrativisation has also simplified the communal nature of the subject of the consultation. Therefore, the complex dimension of indigenous peoples' rights to their territory (as a unit of life with cultural, economic, symbolic, spiritual, productive dimensions) is dissected into measurable units. This ultimately imposes an

\footnotetext{
${ }^{41}$ A regulatory analysis of the constituent elements of the Consultation, a critical overview of the latest proposals made, and the threats to indigenous peoples' perspective can be seen in Martínez de Bringas, 2012, pp. 127-149; Patiño Palacios, 2014, pp. 70 y ss.

${ }^{42}$ I/A Court H.R. Case of the Kichwa Indigenous People of Sarayaku v. Ecuador. Merits, Reparations, and Costs (MRC) 2012, para. 164.

${ }^{43}$ Report of the Special Rapporteur on the situation of human rights and fundamental freedoms of indigenous people, James Anaya. Doc. A/HRC/12/34, 15 July 2009, para. 46.

${ }^{44}$ Ibid., para. 49.
} 
individualising logic (based on the liberal concept of private property) on the indigenous way of understanding the meaning of Consultation. In addition, the methods and manner of consultation and the procedure employed have become prominent and discarded the material content, namely indigenous peoples' rights to their territory and the ensuing rights. The formal dimension of law thus replaces and supersedes the material dimension of law.

Reversing the content of the right to consultation' involves constructing a public discourse that places indigenous peoples as enemies of progress and development, as subjects opposed to the common good, displaying a clear neoliberal bias. The indigenous territory operates as a brake, a solid lock that hinders both private and public investment. The discourse of 'development' demands a flexible use of the territory, and, therefore, of the logic of Consultation. If indigenous peoples continue to engage in a consultation discourse that in practice e places a veto on investments in their territory, this is a bargaining affront to the State's fragmented sovereignty and territory. Therefore, a flexible, instrumental concept of corporate social responsibility is used to dismiss indigenous peoples' rights (Arévalo, 2014, pp. 115 y ss.).

3.2. Indigenous Autonomy is a fundamental right for constructing and reconceptualising indigenous peoples' communal. However, autonomy, in its forms of construction and development has been interpreted antagonistically by indigenous peoples and by the State. For indigenous peoples it entails the strengthening and development of their forms of production, reproduction and individual and collective lives, that is, institutionalising the emancipatory dimension of their political subjectivity. For States it has been conceived as a means to focus on legitimising forms of State governance that allow indigenous peoples to become integrated into States. For States it is somewhat a concession, a new social agreement to manage the 'indigenous issue' differently within a renewed public policy (Anaya 2009; Martínez de Bringas, 2018, pp. 101-138).

To speak, therefore, of the instrumentalisation of indigenous autonomy involves redirecting it to mere public policy, a process of indigenous integration that ignores and relegates the substantially political dimension of autonomy, simply reducing it a State sovereignty issue. ${ }^{45}$ This leaves behind 'plurinationality', a rich term designed to build a new framework of relations with the State, where plurinational pacts intersect to synchronise and intertwine indigenous peoples' rights over their territory with State positions, in an autonomous space that transcends mere administrative decentralisation (Dahl, 2020)

The administrativisation of indigenous autonomy and its consequent depoliticisation implies diluting and neutralising the essential content of this right, namely indigenous communal property as recognised by the IACHR under Article 21 of the ACHR; traditional

\footnotetext{
${ }^{45}$ It is precisely when the issue of State sovereignty is transcended (using a category such as plurinationality) that a State power can be considered it its full complexity. The mechanisms, techniques and tactics that have served to maintain the colonial structure and power thus can then be unveiled by resorting to restoration supported and proposed by indigenous autonomy.
} 
indigenous knowledge located and linked to the territory and its ways of life; economic, social and political control of the territory; and the management of food sovereignty within their own forms of development (Martínez de Bringas, 2018, p. 110).

A rigorous interpretation and application of indigenous autonomy would have important consequences for the configuration and delimitation of the State. It would imply implementing legal pluralism in its broadest sense, beyond constitutional single-jurisdiction approaches and International Human Rights Law itself(Yrugoyen, 2016); plurinationality, which would allow a readjustment and integration of indigenous nations into the State, beyond purely state-centric structures, such as American federalism; and interculturality as a fundamental hermeneutical criterion to understand the relations between State and indigenous peoples. Autonomy as a right requires adapting the indigenous territory to the sovereignty of the State. It also demands reshaping State sovereignty based on the parameters of indigenous peoples' worldviews about their territory, rights, autonomy, law and sovereignty.

4. Finally, we could talk about the postmodern emergence of new threats and risks for indigenous peoples. One is the new global neo-extractivist policy, particularly tested in Latin America; and, concomitantly and interdependently linked to the above, the criminalisation of indigenous peoples for their defence of their rights and territory. All of these open new avenues for thinking and rehearsing strategic litigation.

4.1. Neo-extractivism in Latin America has resulted from a transition from the Washington Consensus to the consensus of commodities (Svampa, 2018, pp. 24-31; 2019). ${ }^{46}$ This makes the exploitation of natural resources the axis along which the new global surplus value, the new niches of wealth and exploitation for capital emerge (which, paradoxically, are occupied, inhabited and protected by indigenous peoples). Neoextractivism demands realigning the economy with the primary sector, which involves adopting intensive and extensive exploitation of its resources as a new productive criterion. It is a social form of territorialisation, a special way of understanding development for capital, and a new postcolonial expression of dispossession for indigenous peoples.

Neo-extractivism, as a new and renewed attack on the rights of indigenous peoples has a circular outline: (i) it demands indigenous territorial dispossession due to the existence of projects that involve large investments in these territories ${ }^{47}$ (for oil exploitation; for open pit mining; for hydrocarbon exploitation; for farming industry focused on the monoculture of soybeans, palm-oil, etc; for large construction works and communications projects across indigenous territory); (ii) territorial dispossession produces inequality, discrimination and exclusion among indigenous peoples, making them one of the most vulnerable and persecuted groups on the planet; and (iii) the final step in this process is the

\footnotetext{
${ }^{46}$ IACHR, Indigenous peoples, Afro-descendant communities and natural resources: protection of human rights in the context of extraction, exploitation and development activities, OEA / Ser.L / V / II. Doc. 47/15, December 312015.

${ }^{47}$ Report of the Special Rapporteur on the situation of human rights and fundamental freedoms of indigenous people, Victoria Tauli Corpuz, Doc. A / HRC / 33/42, 11 August, 2016, para. 83.
} 
criminalisation of indigenous peoples as a result of their militant and defensive attitude towards this social model of territorialisation. ${ }^{48}$

This new social model of production and exploitation involves centralising struggles and resistance in what has been called ecological and territory defence, which bring together a plethora of movements, including ecologists, peasants, feminists, postcolonialists, communal movements, indigenous movements, etc. The core of the demand of new and old rights revolves around the simplification and denial of the social conflict that new neo-extractivism entails, whereby ecological and territory damages are nothing other than externalities, necessary requirements for a productive development model. However, from the indigenous perspective it is necessary to include the ecological and territory variable in the capital-labour conflict, as it applies to the indigenous and peasant population. This would make it possible to map out and conceptualise new attacks against communal rights, such as indigenous peoples' rights to their territory, traditional knowledge, environmental and eco-territorial impacts, food sovereignty, new biodiversity fractures, and the emerging damage from bio-industry, among many other issues.

A systematic review can be made of the advances in this sensitive matter, such as the insertion of due diligence in non-binding supranational rules, such as the Guiding Principles and the OECD Guidelines (OECD, 2018); also in hard law, through comparative law, notably in the French law; ${ }^{49}$ and the draft treaty on transnational corporations and their supply chains with respect to human rights. ${ }^{50}$ But some serious difficulties and setbacks can also be identified, such as the lack of an adequate treatment of indigenous rights in the International Investment Agreements, which leave indigenous peoples totally unprotected, while at the same time negotiating other due diligence practices; how prioritising investment always results in harmful arbitration for indigenous peoples; and the exclusion of indigenous peoples from investment negotiation agreements between businesses and the State. This is an emerging strategic litigation niche that requires refocusing efforts and strategies.

4.2. Indigenous criminalisation is nothing but the reverse of the above process: an aggressive, systematic and relentless reaction to the processes of collective defence of the territory by indigenous peoples faced with the new paradigm of dispossession and illegal occupation (Martínez de Bringas y Milton Yulán, 2019). ${ }^{51}$ Expressive violence against indigenous peoples is therefore exercised against them because they are indigenous peoples, and they have ways of life (preservation, sustainability, reciprocity) that are harmful to the interests of large investments. The criminalisation of the struggle of indigenous peoples therefore has a collective physiognomy.

\footnotetext{
${ }^{48}$ Report of the Special Rapporteur on the situation of human rights and fundamental freedoms of indigenous people, Victoria Tauli Corpuz, Doc. A/HRC/39/17, 10 August 2018, para. 47.

${ }^{49}$ LOI no. 2017-399 of 27 March 2017, regarding the duty of supervision of parent companies and main contractor companies.

${ }^{50} \mathrm{http} / / /$ omal.info/img/pdf/treaty_draft-es.pdf.

${ }^{51}$ Ibid., paras. 27-39; IACHR, Report on Criminalisation of the work of human rights defenders, paras. 57 and 63 to 71 .
} 
When one analyses the patterns of violence against these peoples, the common modus operandi shows the intent to systematic annihilate the structures of indigenous peoples' life, their cultural patterns of functioning and existence. ${ }^{52}$ That is, the aim is to devastate those ways of life on the grounds of their cultural and collective specificity, and of their special relationship with nature and the territory. ${ }^{53}$ It is precisely these ways of life that put a limit and radically oppose to the economic and social model of territorialisation and development advocated by neo-extractivism.

The indigenous paradigm of Good Living, with obvious principles such as relationality, complementarity, reciprocity or the cyclical nature of life, constitutes a direct attack on the extractive model of dispossession, annihilation and consumption. By systematising and conceptualising the patterns of discrimination and exclusion of indigenous peoples,${ }^{54}$ one can understand the ultimate purpose of this form of violence: denying and destroying the ontological dimension of indigenous peoples, their life practices, their forms of organisation, precisely because they restrict and bring losses to public and private interests, including States, companies and private third parties, among others. We are, therefore, faced with a titanic confrontation between two antagonistic models of understanding economics, development, sustainability and modes of protection. This has also resulted in the development of criminal laws tailored made to persecute the struggle of indigenous peoples and their ways to protest against the new threats to their communal way of inhabiting and defending their territory. These are precisely the direct causes of criminalisation of indigenous peoples.

These areas demand intense strategic work of regulatory and political struggle, as they are the current source of the deep wound inflicted on indigenous peoples.

\section{Conclusions}

1. One of the central axes of this study has been the collective nature of indigenous peoples, as expressed in the phrase 'collective rights'. This is mediated through strategic litigation, due to its importance as a lever for decolonisation. The collective (as a form of expression and work) is essential in the production, reproduction and development of indigenous life. Indigenous peoples' communal institutions are sources of decision making, channels for the reproduction of daily life on communal lands. This is an important counterpoint to the liberal discourse that atomises the collective, fragmenting its sovereign decision-making power on the basis of an individual discourse of rights.

To show the power of the collective, this dimension has been re-signified by resorting to the interpretations made by some bodies that oversee the UN system treaties

\footnotetext{
${ }^{52}$ I/A Court H.R. Case of the Plan de Sánchez Massacre v. Guatemala. Background. Judgment of 29 April 2004. Series C No. 105, paras. 70-78.

${ }^{53}$ I/A Court H.R. Case of the Saramaka People v. Suriname. EPFRC 2007, paras. 167-172.

${ }^{54}$ Indigenous genocide is included in this; the violent expulsion, deprivation and dispossession of their ancestral territories; the persecution and killing of their leaders, and of their forms of collective selforganisation; and the plundering and looting of indigenous heritage, among others.
} 
(Estupiñan Silva and Ibañez Rivas, 2014, pp. 304 y ss.). A series of judgments of the InterAmerican Court have also been selected to demonstrate the epistemic shift produced by the institutionalisation of rights; using strategic litigation, it has made collective rights a founding core of indigenous rights, and an avenue for designing guaranteeing strategies beyond the individualising rights discourse.

2. The implementation gap has become a mantra that perfectly diagnoses the situation of indigenous peoples' rights and the limits of strategic litigation. Evidence has been provided of the existing split between the regulatory developments in indigenous peoples' rights (within the UN and the IACHR) and the reality of rights violations. As regulatory and institutional development increased, indigenous persecution and criminalisation have been intensified Sthrough postmodern expressions of violence. The implementation gap also has had a major impact on the process of depoliticisation of indigenous rights by neutralising their content and the possibility of providing any genuine guarantees; and by reducing the entire strategy of indigenous peoples' struggle to the language of rights and litigating strategies, restricting other political paths of struggle and protest. This has evidenced how difficult it can be to adopt the rights approach as the only alternative to implement the struggle strategy of indigenous peoples and to understand its political dimension.

3. All indigenous conflicts are based around ecological and territory issues. The territory and its collective dimension have an overarching influence on the entire life project of indigenous peoples. It is necessary to how liberal perspectives have failed to turn indigenous peoples into small landowners, as farmers displaced from their communal lands. The limitation of State liberalism is that it addresses this issue from a perspective that allows (State) sovereignty, leaving behind concepts such as plurinationality and sovereignty. This entire process of atomisation and fracturing of the collective has been implemented by the regulatory hand of indigenous peoples' rights and inclusion through citizenship, thereby abandoning indigenous communal specificity, and the centrality of ecological and territory-based issues in the understanding of indigenous peoples' demands.

4. As a consequence of the above, a series of challenges have been set for indigenous peoples in view of the qualitative and quantitative increase in territory-related aggressions. The ecological and territory-based paradigm has brought with it a new exploitation map for the interests of capital. This has had consequences in the treatment and embezzlement of certain indigenous rights such as consultation and autonomy. Consultation has been instrumentalised, which has irreversibly tended to render it void: it has become consultation at the service of States and companies. Autonomy has been fertile ground for the depoliticisation of indigenous rights, given its abstract content and requirements, and for the multicultural policy of insertion by States. Consequently, its content has been somewhat diluted and indigenous peoples' autonomy has become disengaged from its primary source, such as their territory. Hence the new paradigm of indigenous aggression will always be structurally related to territory issues in holistic and collective terms. This opens up new pathways of interpretation and testing in strategic litigation for indigenous peoples' rights. 


\section{REFERENCES}

ANAYA, J. (2009), "The right of indigenous peoples to self-determination in the postDeclaration era", in Making the Declaration Work: The United Nations Declaration on the Rights of Indigenous Peoples, Claire Charters and Rodolfo Stavenhagen, eds., IWGIA, Copenhagen, pp. 184-199.

ARÉVALO, A. (2014), El derecho a la consulta previa de los pueblos indígenas en derecho internacional, Cuadernos Deusto de Derechos Humanos, $n^{0} 76$, Universidad de Bilbao.

AYLWIN, J. (2014), "Los derechos de los pueblos indígenas en América Latina: Avances jurídicos y brechas de implementación" in Jane Felipe Beltrão and others, Derechos humanos de los grupos vulnerables, Red de Derechos Humanos y Educación Superior, Barcelona, pp. 282-294.

BERRAONDO M.(coord.)(2006), Pueblos indigenas y derechos humanos, Universidad de Deusto, Bilbao.

BERRAONDO, M. (2016), La protección de los territorios de los pueblos en aislamiento en América del Sur a partir del desarrollo de los derechos territoriales de los pueblos indígenas, Tesis Doctoral, Universidad de Deusto, Bilbao.

BRUNNER, L. (2008), “The Rise of Peoples'Rights in the Americas: The Saramaka People Decision of the Inter-American Court of Human Rights", en Chinese Journal of International Law, n.o 7, pp. 699-732. https://doi.org/10.1093/chinesejil/jmn031

CITRONI, G. y QUINTANA, K. I. (2008), "Reparations for Indigenous Peoples in the Case Law of the Inter-American Court of Human Rights", en LENZERINI, F. (Ed.) Reparations for Indigenous Peoples, International and Comparative Perspectives. Oxford University Press, New York.

DAHL, J. (2020), Construyendo autonomías, IWGIA, Perú.

DULITZKY, A. (2010), "Cuando los afrodescendientes se transformaron en pueblos tribales: El Sistema Interamericano de Derechos Humanos y las comunidades rurales negras", El Otro Derecho, no 41, 2010, pp. 13-48.

ESTUPIÑAN SILVA R. \& IBAÑEZ RIVAS J. (2014), "La jurisprudencia de la Corte Interamericana de Derechos Humanos en materia de pueblos indígenas y tribales" in Jane Felipe Beltrão and others, Derechos humanos de los grupos vulnerables, Red de Derechos Humanos y Educación Superior, Barcelona, pp. 301-336.

FUND FOR THE DEVELOPMENT OF THE INDIGENOUS PEOPLES OF LATIN AMERICA AND THE CARIBBEAN (2019), Derechos de los Pueblos Indigenas: Marcos Jurídicos e Institucionales en los Estados Miembros del FILAC, La Paz, Bolivia.

IWGIA (2019), El Mundo Indígena, IWGIA, Copenhague.

IWGIA (2020), El Mundo Indígena, IWGIA, Copenhague. 
MARTÍNEZ DE BRINGAS, A. (2012), "El derecho a la consulta de los pueblos indígenas: naturaleza, elementos y procedimientos para su aplicación en el estado", RVAP, $\mathrm{n}^{\circ}$ 93, pp. 127-149.

MARTÍNEZ DE BRINGAS, A. (2018), "Indigenous autonomies in Latin America. A comparative view of the difficulties for the construction of an intercultural Law", Revista d'estudis autonòmics i federals , 28, pp. 101-138.

MARTÍNEZ DE BRINGAS A., YULÁN, M.(2019), Misión de Observación Internacional: Situación de defensoras/es campesinas/os de la tierra y territorio, region de Polochic, Guatemala, Mundu Bat, Bilbao, 2019.

NASH, ROJAS, C.(2008), "Los derechos indígenas en el sistema interamericano de derechos humanos", RIEDH, vol. 1, no 1, pp. 61-86.

OECD (2018), Due Diligence Guidance for Responsible Business Conduct, OECD.

PATIÑO PALACIOS, L. A. (2014), "Fundamentos y práctica internacional del derecho a la consulta previa, libre e informada a pueblos indígenas", en Anuario Colombiano de Derecho Internacional, n.o 7, pp. 69-111. https://doi.org/10.12804/acdi7.2014.03

PENTASSUGLIA, G. (2011), “Towards a Jurisprudential Articulation of Indigenous Land Rights", in European Journal of International Law, no 22(1), pp. 165-202. https:// doi.org/10.1093/ejil/chr005

SALMÓN, E. (2010), Los pueblos indígenas en la jurisprudencia de la Corte Interamericana de Derechos Humanos: Estándares en torno a su protección y promoción, GTZ, Lima, 2010.

SVAMPA, M. (2018), Las fronteras del neoextractivismo en América Latina. Conflictos socioambientales, giro ecoterritorial y nuevas dependencias, Universidad de Guadalajara, México. https://doi.org/10.14361/9783839445266

SVAMPA, M (2019), Neoextractivism in Latin America, Cambridge University Press, Cambridge.

YRUGOYEN, R. (2016), "Pluralismo jurídico y jurisdicción indígena en el horizonte del constitucionalismo pluralista" en H. AHRENS, "El Estado de derecho hoy en América Latina. Libro en homenaje a Horst Schöbohm”, UNAM, Instituto de Investigaciones Jurídicas, 2016, p 174-195.

Received: March $19^{\text {th }} 2020$

Accepted: July $27^{\text {th }} 2020$ 